\title{
Awareness among Graduate Students about Open University of Saran District - A Comparative Study
}

\author{
Archana Kumari*, Sangeeta Deo and Smriti Rekha Sarkar \\ College of Community Science, Pusa, India \\ *Corresponding author
}

\section{Keywords \\ Open Universities, empowerment, gender equality, education}

Article Info

\section{Accepted:}

08 June 2020

Available Online:

10 July 2020

\section{A B S T R A C T}

\begin{abstract}
Women constitute about $50 \%$ of the total population but they form $9 \%$ of the total productive workforce. The main reason for this poor share is low literacy level among women. When this major chunk is educated, no doubt they can contribute significantly for the development of the country. Women empowerment is a global issue. Empowerment is an active multi-dimensional process which enables women to realize their full identity and powers in all spheres of life. In this context, a study was conducted among graduate students of Saran district. The samples of graduate students were selected by purposively sampling technique by selecting 25 students each from Chapra town and village of Saran district. The selected villages were namely Gurdahakhurd, Sugharchhapra, Madipur and Thana bazaar. The data was collected using a specially designed interview schedule. Result of the study revealed that most of the graduate students residing in village of Saran district were unaware about distance education but majority of student of Chapra town were well known to distance education and women empowerment so it can be concluded that due to lack of tools of education, additional knowledge, lack of exposure, they are unknown to the ongoing method of distance education through open universities. Additionally the basic tools and techniques of imparting education is missing in both the villages and towns of Saran district. The only difference that can be observed between the two different socials set-ups is outlook and thought process towards higher education where the deciding factor takes the shape of exposure and awareness about the countless benefits of education.
\end{abstract}

\section{Introduction}

Social inequalities affect the lives of the most of the Indian women. They are often segregated from the main stream of education, employment, rights and empowerment. The difference in roles between men and women was determined by the gender of the individual. Clearly there can be no change unless women are able to take charge of their own lives and over the financial and material resources. In other words, women need to be empowered. Women can be empowered by education. Education has direct impact on women empowerment as it creates in them awareness about their rights, their capabilities, the choice and opportunities available to them.

Literacy among women opens the possibility of unlimited exposure to new information and more importantly to new ways of thinking and new perspectives on existing information. Literate women are able to constructively 
express their talent and give direction to their aptitude.

Women can be literate by getting education by attending school and college through traditional system and also by getting degree from distance education. Distance Education is a global and rapidly growing phenomenon which offers formal learning opportunities to people who would not otherwise have access to schooling or college education. Teachers and students are separated by physical distance and the means by which they communicate range from basic print material and the use of postal services to highly sophisticated communication technologies. Distance Education has emerged as a boon to women of all ages to equip themselves intellectually through acquisition of knowledge, leading them to new radical methods of thinking, and alternative, lateral perspectives on existing information thus rendering them more autonomous and liberated.

Women constitute about fifty percent of the total population, but they form only nine percent of the total productive work force. The main reason for this poor share is low literacy level among women. When this major chunk is educated, no doubt, they can contribute significantly for the development of the country and can there by empower themselves.

The research work was conducted in Saran district, where the total number females were 1, 59,614 and literacy rate, a meager $35 \%$ according to District HQ data.

\section{Materials and Methods}

The study was conducted to understand the awareness among graduate students about distance education on residing in saran district. The sample of 50 students was selected purposively sampling technique. Out of 50 respondents, 25 respondents were from Chapra town and village each. The data was collected using a specially designed interview schedule and observation technique in the colleges of town and village of Saran district. The selected villages were namely Gurdahakhurd, Sugharchhapra, Madipur and Thana bazaar.

\section{Results and Discussion}

By seeing this table-1, it may be observed that $42 \%$ parents were literate, $58 \%$ were illiterate, and $56 \%$ respondents belong to nuclear type family and $64 \%$ from joint family. Out of 50 respondents, $52 \%$ respondents were from medium size family and $48 \%$ belong to large family. Respondents belonging to different income groups viz. Low, Medium and high were $36 \%, 42 \%$ and $22 \%$ respectively.

It can be observed in the table no.5 that lack of education and exposure once again hampered the overall general thinking of the students residing in villages who were of the opinion that educating women can hamper decision making of a family and there will be clashes among the male and female group of the family, thus rupturing the smoothness of running their family. For family stability women should not more educated. While a total opposite trend was seen in the town where most of the students who were open to better education and were given encouragement to study thought through education one can be a financial help to the family apart from recognition of the family as "well-educated". They also had opinion that family can be managed in a better way as problem solving would become easier through an extra helping hand of the women in the family. It can be observed in table no. 8 that respondents from town were totally aware of the education through Open Universities while most of the respondents from village were unaware about this education system. 
Table 8 indicates that none of the respondents from village took the degree from Open University, all had completed the degree from college but only 2 respondents from town took the degree from Open University.

This indicates that least number of respondents had any kind of knowledge or interest in taking degree from Open Universities which also depicts that they had least knowledge about the existing education methods. The table depicts the reason for opting the degree course from Open Universities where most of the respondents had the issue of parallel recognition as compared to general universities where the value of degree remains the same or at par with the general universities. Availability of diverse courses was another reason for which most of the respondents wanted to pursue degree at OU. While not pursuing degree from OU were opted by most of the respondents as according to them 5-6 general colleges were available for them to pursue their degrees by taking full time courses.

We can say by seeing the table no.10 that village respondents told that Open Universities are useful for daughter in law and girls who are not allowed to go outside the home, useful in village condition where there more social insecurity while respondents from town told that it beneficial for working lady, village/town lacking good colleges and girls who are not allowed to go to college and take full time courses.

The only factor which was supported in unison by both the genres of the society was lack of proper colleges in their social areas.

Table.1 Profile of the parents of respondents

\begin{tabular}{|l|c|c|c|c|c|c|c|c|c|}
\hline Particulars & \multicolumn{2}{|c|}{ Parent's literacy } & \multicolumn{2}{|c|}{ Family type } & \multicolumn{2}{c|}{ Family size } & \multicolumn{3}{|c|}{ Income group } \\
\cline { 2 - 11 } & Literate & Illiterate & Nuclear & Joint & Medium & Large & L & M & H \\
\hline $\begin{array}{l}\text { No. of } \\
\text { respondents }\end{array}$ & 21 & 29 & 28 & 22 & 26 & 24 & 18 & 21 & 11 \\
\hline
\end{tabular}

Table.2 Effects of educating women

\begin{tabular}{|l|c|c|}
\hline \multicolumn{1}{|c|}{ Particulars } & Village respondents & Town respondents \\
\hline Family will be wisely managed & 4 & 23 \\
\hline Family will be educated & 9 & 25 \\
\hline Assistance in financial help & 4 & 17 \\
\hline Participation in taking decision & 2 & 25 \\
\hline Broader way of thinking & 4 & 22 \\
\hline Family cannot run smoothly & 12 & 2 \\
\hline $\begin{array}{l}\text { Interference in family decision } \\
\text { making }\end{array}$ & 19 & 2 \\
\hline
\end{tabular}

Table.3 Heard about Open University

\begin{tabular}{|l|c|c|}
\hline \multicolumn{1}{|c|}{ Particulars } & Yes & No \\
\hline Respondents from village & 4 & 21 \\
\hline Respondents from town & 25 & \\
\hline
\end{tabular}


Table.4 Degree completed from college or Open University

\begin{tabular}{|l|c|c|}
\hline \multicolumn{1}{|c|}{ Particulars } & College & Open university \\
\hline Respondents from village & & 25 \\
\hline Respondents from town & 23 & 2 \\
\hline
\end{tabular}

Table.5 Reasons for opting/pursuing degree from Open University

\begin{tabular}{|l|c|c|}
\hline \multicolumn{1}{|c|}{ Particulars } & Respondents from village & Respondents from town \\
\hline $\begin{array}{l}\text { Parallel recognition/at par with } \\
\text { general universities }\end{array}$ & 18 & 13 \\
\hline $\begin{array}{l}\text { Availability of diverse courses } \\
\begin{array}{l}\text { Don't want to pursue degree } \\
\text { from OU }\end{array}\end{array}$ & 9 & 10 \\
\hline
\end{tabular}

Table.6 Beneficiaries of Open Unviersities

\begin{tabular}{|l|c|c|}
\hline \multicolumn{1}{|c|}{ Particulars } & Respondents from village & Respondents from town \\
\hline Daughter in law & 15 & 6 \\
\hline $\begin{array}{l}\text { Girls not allowed to go outside } \\
\text { the home }\end{array}$ & 17 & 11 \\
\hline $\begin{array}{l}\text { Girls facing social insecurity } \\
\begin{array}{l}\text { Girls who are not allowed to go } \\
\text { to college. }\end{array}\end{array}$ & 14 & 10 \\
\hline $\begin{array}{l}\text { Beneficial for the working lady } \\
\text { Villages/towns lacking proper } \\
\text { colleges }\end{array}$ & 10 & 18 \\
\hline
\end{tabular}

The whole research was conducted to understand the awareness level of the girl students about the role of open universities which was successfully revealed through proper information gathering and then formulating a general outlook of the fellow respondents.

The social structure, to which the respondents belonged to, had a direct impact on their opinions and knowledge levels. The more the exposure, the more intensified and developed thought process and vice versa. The educated section of the society also displayed exemplary understanding and inspiring mental structure to accept change and understand its benefits.
The respondents from village section of the district had opinions which were clearly marred by factors including illiteracy, social backwardness and lack of infrastructure. The section of the society had only $42 \%$ literates though bettering their overall district's average of $35 \%$ by $7 \%$. Still the kind of education given to them lacked direction as they were unable to reply to simple questions viz. What is open University and what are its benefits.

Some had vague idea saying it is just a general university open for all classes of the society while some said it is the same as a general university. When asked about women empowerment, some said it is just about 
getting a government job or getting education while many simply said empowerment is directly dependant on how the family provides them food, shelter or social security. The more these facilities are given by the family, the more empowered a woman becomes. Women empowerment is a diversified issue of discussion and implementation where family's treatment of the girl(s) holds a very meager importance as issue of empowerment revolves around stronger factors like education, social security and gender equality.

Most of the respondents did not support women empowerment and nor did they want education through open universities as most of these families were socially oppressed and menaced by male chauvinism. Most of the girls were not allowed to go out of their home and many of them were not allowed to study after completing higher secondary education. The education system of Open universities will be useful for this section of the society as well as for married women who have an added responsibility of family welfare.

Respondents from town showed signs of intellect by supporting empowerment and education for girls even after higher secondary education. Their thoughts idealized empowerment as a method of improving family status, family welfare, independence and participation in decision making and also fighting for their rights. They wanted these kinds of facilities in remote areas which lack proper colleges and girls are devoid of further education.

Most importantly, they also suggested improving infrastructure of villages and installing an education system which monitors the enrollment and development of these women/girls apart from giving them necessary study materials and imparting education through well constituted course curriculum. The respondents also said that their town has 5-6 general colleges through which they can complete their degree. The only motivating factor in favour of Open Universities would be their diversified or exclusive degree courses.

They also wanted the degree of Open Universities to be treated at par with general universities so that they are able to get a job on will. The last suggestion that they gave was to give free education to the down trodden and families below poverty line who cannot afford to pay fees or give scholarships to girls who have performed well at school level.

The step to introduce scholarships or free education will not only inspire and motivate the girls to study further but will also relieve them of any financial burden. The education will not only improve family status but also shape a new career and open up new options, thereby strengthening the weaker section of the society. Empowering women will decrease social inequalities and finally will put India's new face of empowered social structure on world stage.

\section{References}

Adams, R. (1990) Self-Help, Social Work and Empowerment. London, UK : Macmillan

Gopalan, S., Thukral , E. and Kaur,G (200) Status of Women. N. Delhi, India: IGNOU

Janaki, D. Empowering Women through Distance Learning in India.

Moghadam, Valentine, M. 'Wider Research for Action, Gender Development and Policy: Towards Equity and Empowerment', World Institute for Development Research of the United Nations University, 1990.

Shahay, Sushama. 'Women and 
Empowerment - Approaches and Sharma, Motilal. 'Issues in Distance Strategies', Discovery Publishing House, New Delhi, 1998. Education, in Distance Education', Volume I, Asian Development Bank.

\section{How to cite this article:}

Archana Kumari, Sangeeta Deo and Smriti Rekha Sarkar. 2020. Awareness among Graduate Students about Open University of Saran District - A Comparative Study. Int.J.Curr.Microbiol.App.Sci. 9(07): 633-638. doi: https://doi.org/10.20546/ijcmas.2020.907.072 